Mor phol ogi cal Anal ysi s of Li ve Undi fferent i at ed Cel I s Der i ved from I nduced Pl uri pot ent St em Cel I s.

\begin{tabular}{|l|l|}
\hline 著者 & $\begin{array}{l}\text { Osawa Yuki hi ko, M yanmt o Tomoyuki, Ohno } \\
\text { Set suyo, Onno Ei j i }\end{array}$ \\
\hline 学位名 & 博士 (保健科学) \\
\hline 学位授与機関 & 九州保健福祉大学 \\
\hline 学位授与年度 & 平成29年度 \\
\hline 学位授与番号 & 博甲ツ056号 \\
\hline URL & ht t p: //i d. ni i .ac.j p/1147/00001329/ \\
\hline
\end{tabular}


Morphological Analysis of Live Undifferentiated Cells Derived From Induced Pluripotent Stem Cells

iPS 細胞に由来する生存未分化細胞の形態学的解析

$$
2018 \text { 年 } 3 \text { 月 }
$$

九州保健福祉大学大学院

(通信制) 保健科学研究科

保健科学専攻

D211501 大澤 幸希光 
今回、本論文の内容が掲載された雑誌の表紙デザインに採用された。
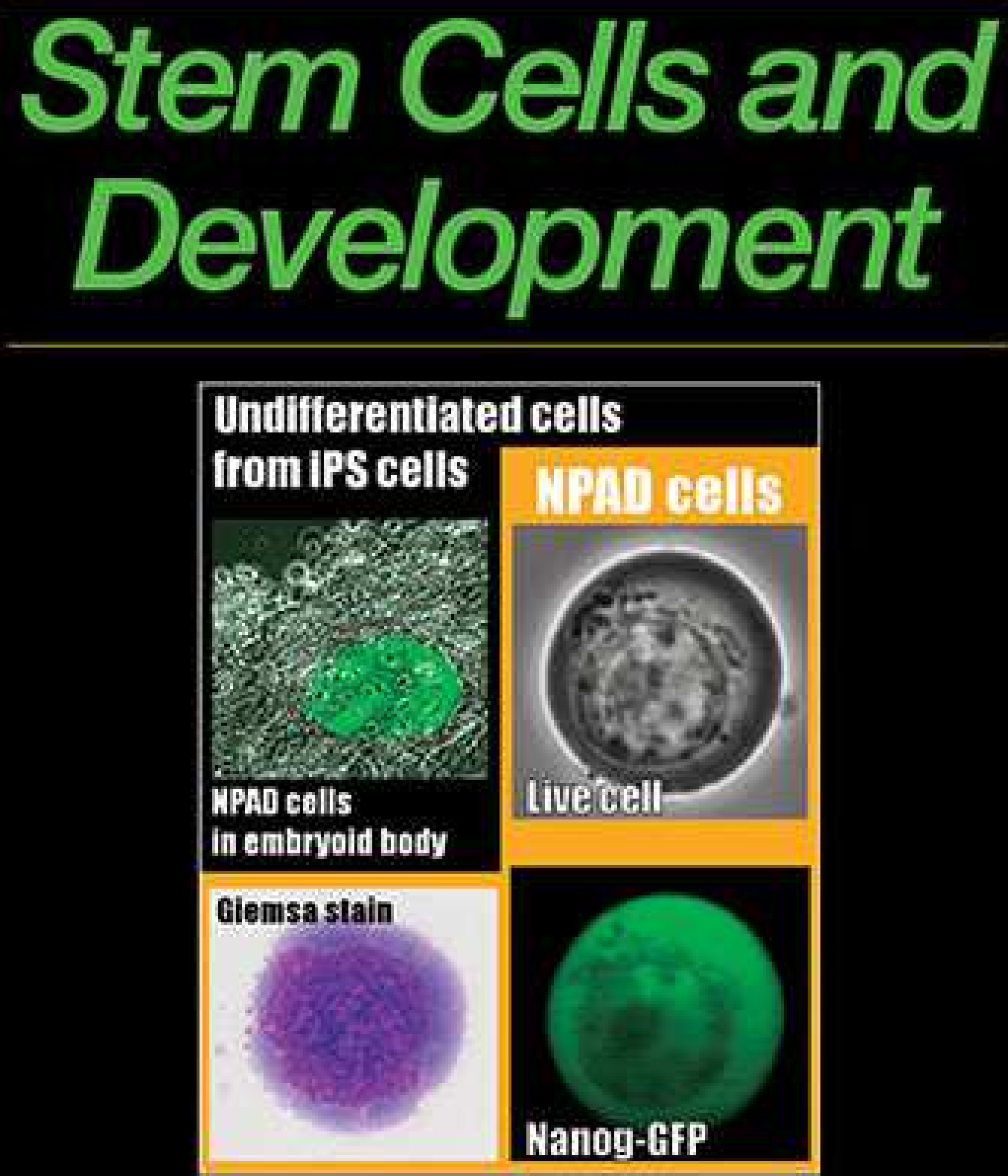

Many Ann Lielert, Ine. F pullishen

Stem Cells and Development (Volume 27 , Number 1) Impact Factor of Stem Cells and Development : 3.562 


\title{
Morphological Analysis of Live Undifferentiated Cells Derived from Induced Pluripotent Stem Cells
}

\author{
Yukihiko Osawa, ${ }^{1,2}$ Tomoyuki Miyamoto, 2,3 Setsuyo Ohno, ${ }^{1-3}$ and Eiji Ohno ${ }^{1-3}$
}

Induced pluripotent stem (iPS) cells possess pluripotency and self-renewal ability. Therefore, iPS cells are expected to be useful in regenerative medicine. However, iPS cells form malignant immature teratomas after transplantation into animals, even after differentiation induction. It has been suggested that undifferentiated cells expressing Nanog that remain after differentiation induction are responsible for teratoma formation. Various methods of removing these undifferentiated cells have therefore been investigated, but few methods involve morphological approaches, which may induce less cell damage. In addition, for cells derived from iPS cells to be applied in regenerative medicine, they must be alive. However, detailed morphological analysis of live undifferentiated cells has not been performed. For the above reasons, we assessed the morphological features of live undifferentiated cells remaining after differentiation induction as a basic investigation into the clinical application of iPS cells. As a result, live undifferentiated cells remaining after differentiation induction exhibited a round or oval cytoplasm about $12 \mu \mathrm{m}$ in diameter and a nucleus. They exhibited nucleo-cytoplasmic (N/C) ratio of about $60 \%$ and eccentric nuclei, and they possessed partially granule-like structures in the cytoplasm and prominent nucleoli. Although they were similar to iPS cells, they were smaller than live iPS cells. Furthermore, very small cells were present among undifferentiated cells after differentiation induction. These results suggest that the removal of undifferentiated cells may be possible using the morphological features of live iPS cells and undifferentiated cells after differentiation induction. In addition, this study supports safe regenerative medicine using iPS cells.

Keywords: iPS cells, morphological analysis, undifferentiated cells, live cells

\section{Introduction}

IN 1981, Evans and Kaufman established embryonic Istem (ES) cells, which were pluripotent stem cells derived from the inner cell mass of a mouse blastocyst for the purpose of producing genetically modified mice [1]. ES cells are expected to be useful in regenerative medicine because they exhibit self-renewal ability and pluripotency. However, the use of ES cells involves the ethical issue of destroying an embryo when establishing the cell line, and it can also cause tissue rejection following cell transplantation therapy [2].

To resolve these problems of ES cells, Yamanaka and colleagues established induced pluripotent stem (iPS) cells with self-renewal ability and pluripotency equivalent to those of ES cells by introducing reprogramming factors $(O c t 3 / 4, K l f 4$, Sox $2, c-M y c)$ into mouse and human somatic cells $[3,4]$. iPS cells can be produced using the somatic cells of a patient. Therefore, they overcome the ethical and tissue rejection problems of ES cells and can be used for transplantation into patients [4].
However, iPS cells form malignant immature teratomas after transplantation into animals [5]. When iPS cells are clinically applied, they are used after the induction of differentiation into target cell types. However, transplanted cells that have undergone differentiation induction also have the ability to form tumors [5-7]. In our previous study, we confirmed that the tumors formed by these cells after differentiation induction were malignant immature teratomas [5]. It has been suggested that undifferentiated cells expressing Nanog that remain after differentiation induction are responsible for teratoma formation [5].

In mouse iPS cells, Nanog expression can be visually detected as fluorescence by introducing the green fluorescent protein $(G F P)$ gene downstream of the Nanog promoter [8]. Therefore, in mouse iPS cells with the Nanog-GFP gene fusion, it is possible to remove undifferentiated cells expressing Nanog before transplantation.

However, when human iPS cells are clinically applied, methods that do not depend on genetic modification are necessary. For the above reasons, we report here the morphological

${ }^{1}$ Graduate School of Health Science Studies, ${ }^{2}$ Cancer Cell Institute, and ${ }^{3}$ Department of Medical Life Science, Faculty of Medical Bioscience, Kyushu University of Health and Welfare, Nobeoka, Japan. 


\section{Abstract}

Induced pluripotent stem (iPS) cells possess pluripotency and self-renewal ability. Therefore, iPS cells are expected to be useful in regenerative medicine. However, iPS cells form malignant immature teratomas after transplantation into animals, even after differentiation induction. It has been suggested that undifferentiated cells expressing Nanog that remain after differentiation induction are responsible for teratoma formation. Various methods of removing these undifferentiated cells have therefore been investigated, but few methods involve morphological approaches, which may induce less cell damage. In addition, for cells derived from iPS cells to be applied in regenerative medicine, they must be alive. However, detailed morphological analysis of live undifferentiated cells has not been performed. For the above reasons, we assessed the morphological features of live undifferentiated cells remaining after differentiation induction as a basic investigation into the clinical application of iPS cells.

As a result, live undifferentiated cells remaining after differentiation induction exhibited a round or oval cytoplasm about $12 \mu \mathrm{m}$ in diameter 
and a nucleus. They exhibited nucleo-cytoplasmic (N/C) ratio of about $60 \%$ and eccentric nuclei, and they possessed partially granule-like structures in the cytoplasm and prominent nucleoli. Although they were similar to iPS cells, they were smaller than live iPS cells. Furthermore, very small cells were present among undifferentiated cells after differentiation induction. These results suggest that the removal of undifferentiated cells may be possible using the morphological features of live iPS cells and undifferentiated cells after differentiation induction. In addition, this study supports safe regenerative medicine using iPS cells. 


\section{要旨}

人工多能性幹細胞 (iPS 細胞) は分化多能性と自己複製能を有している。 また、iPS 細胞は患者自身の体細胞からも作製可能であるため胚性幹細胞 (ES 細胞) の抱える倫理問題や移植後の拒絶反応の問題を克服している。そ のため iPS 細胞は、器官や組織を病気や怪我によって失った場合にそれら を構成する細胞あるいは組織を移植し再生する、再生医療への応用が期待 されている。しかし iPS 細胞は未分化状態のまま生体に移植すると悪性の 未熟奇形腫を形成する。そのため再生医療に用いる際は iPS 細胞を目的と する細胞種へと分化誘導する必要があるが iPS 細胞を分化誘導した後の細 胞群を用いても移植後に悪性の未熟奇形腫を形成し得る。このことは Nanog を発現する未分化細胞が分化誘導後も残存することが原因と考えら れている。現在様々な未分化細胞の除去法が検討されているが細胞傷害の 少ない形態学的な手法を用いた方法は皆無である。そこで我々は、iPS 細胞 の臨床応用のための基盤研究の一環として、分化誘導後に残存する未分化 細胞の生存状態における形態学的特徵を検討した。再生医療への応用を想 定した場合、移植する細胞は生細胞であることが必須である。 その結果、分化誘導後に残存寸る生存未分化細胞は細胞質及び核が円形あ るいは類円形で直径が約 $12 \mu \mathrm{m}$ の細胞であった。核/細胞質比は約 $60 \%$ 
で偏在核であり、細胞質内の一部に顆粒様構造を有し、核内には明瞭な核 小体を有していた。また、分化誘導後に残存寸る未分化細胞は iPS 細胞に 類似するも iPS 細胞に比して小型であった。加えて、これらの細胞とは異 なる非常に小型の未分化細胞も認められた。以上のような我々の提示した 形態学的所見を検討、評価することにより未分化細胞の除去が可能である。 また、我々の報告は iPS 細胞を用いた安全な再生医療実現の一助になると 示唆された。 


\section{Introduction}

In 1981, Evans et al. established embryonic stem (ES) cells, which were pluripotent stem cells derived from the inner cell mass of a mouse blastocyst for the purpose of producing genetically modified mice ${ }^{1)}$. ES cells are expected to be useful in regenerative medicine because they exhibit self-renewal ability and pluripotency. However, the use of ES cells involves the ethical issue of destroying an embryo when establishing the cell line, and it can also cause tissue rejection following cell transplantation therapy ${ }^{2)}$.

In order to resolve these problems of ES cells, Yamanaka et al. established induced pluripotent stem (iPS) cells with self-renewal ability and pluripotency equivalent to those of ES cells by introducing reprogramming factors $(O c t 3 / 4$, Klf4, Sox2, $c-M y c)$ into mouse and human somatic cells ${ }^{3,4)}$. iPS cells can be produced using the somatic cells of a patient. Therefore, they overcome the ethical and tissue rejection problems of ES cells and can be used for transplantation into patients ${ }^{4)}$. However, iPS cells form malignant immature teratomas after transplantation into animals ${ }^{5)}$. When iPS cells are clinically applied, 
they are used after the induction of differentiation into target cell types. However, transplanted cells that have undergone differentiation induction also have the ability to form tumors ${ }^{5-7)}$. In our previous study, we confirmed that the tumors formed by these cells after differentiation induction were malignant immature teratomas ${ }^{5}$. It has been suggested that undifferentiated cells expressing Nanog that remain after differentiation induction are responsible for teratoma formation ${ }^{5}$.

In mouse iPS cells, Nanog expression can be visually detected as fluorescence by introducing the green fluorescent protein $(G F P)$ gene downstream of the Nanog promoter ${ }^{8)}$. Therefore, in mouse iPS cells with the Nanog-GFP gene fusion, it is possible to remove undifferentiated cells expressing Nanog before transplantation.

However, when human iPS cells are clinically applied, methods that do not depend on genetic modification are necessary. For the above reasons, we report here the morphological features of live undifferentiated cells that remain after differentiation induction, termed residual NPAD (Nanog-GFP-positive after differentiation) cells, as part of a basic investigation into the clinical application of iPS cells. 


\section{Materials and Methods}

\section{Cell culture}

The mouse iPS cell line iPS-MEF-Ng-20D-17 (APS0001; RIKEN Bioresource Center, Japan) used in this study expresses GFP under the control of the Nanog promoter ${ }^{8)}$. Undifferentiated cells express Nanog, but its expression disappears with differentiation ${ }^{8,9)}$.

Gelatin from porcine skin (Sigma-Aldrich, USA) was added as a 0.1\% aqueous solution to a cell culture dish (Becton Dickinson Labware, USA) and incubated at $37^{\circ} \mathrm{C}$ for 30 minutes, and a gelatin coat was applied to the culture dish. EmbryoMax ${ }^{\circledR}$ Primary Mouse Embryo Fibroblasts (MEFs; Millipore, USA) treated with mitomycin C (Kyowa Hakko Kogyo Co., Ltd., Japan) were seeded in gelatin-coated culture dishes. The iPS cell line was seeded on mitomycin C-treated MEFs and cultured in ES medium [15\% fetal bovine serum (FBS; MP Biomedicals, USA), $1 \%$ non-essential amino acids (Millipore, USA), $1 \%$ nucleosides (Millipore, USA), and 1\% Dulbecco's modified Eagle's medium (Wako Pure Chemical Industries, Ltd., Japan) containing 1\% L-glutamine (MP Biomedicals, USA), 500U/mL ESGRO ${ }^{\circledR}$ Mouse Lukemia Inhibitory 
Factor (LIF; Millipore, USA), 2( $\beta$ )-mercaptoethanol (Sigma-Aldrich, USA), and 1\% penicillin-streptomycin (Millipore, USA)]. The medium was exchanged every day.

iPS cells were passaged once every 2-3 days. For the dispersion of iPS cells, $2.5 \mathrm{~g} / \mathrm{L}$ trypsin EDTA solutions were used.

Differentiation induction of iPS cells

iPS cells dispersed with enzyme (trypsin) were seeded at $5 \times 10^{4} / \mathrm{mL}$ on a low-adhesion culture dish (Corning, USA) and suspension-cultured. For the culture, $10 \mathrm{~mL}$ of feeder cell culture medium (ES cell culture medium without LIF) was used. On day 7 after the seeding, the formed embryoid bodies (most of the embryoid bodies, including both GFP-positive and -negative cells) were transferred to gelatin-coated cell culture dishes, and adhered and cultured for 3 days (Fig. 1).

Cells expressing Nanog-GFP even after the induction of differentiation for a total of 10 days were defined as NPAD cells (Fig. 2). NPAD cells were dispersed using an enzyme and morphologically analyzed. 


\section{Cell sorting}

iPS, NPAD, and GFP-negative cells were stained with $1.0 \mu \mathrm{g} / \mathrm{mL}$ propidium iodide solution (PI; Sigma-Aldrich, USA) for 5 minutes. Stained cells were spun down at $250 \mathrm{~g}$ for 5 minutes and washed with sorting buffer [minimum essential medium (MEM; gibco $\left.{ }^{\circledR}, \mathrm{USA}\right)+2 \%$ FBS] and spun down again at $250 \mathrm{~g}$ for 5 minutes. Pellets were resuspended in $3 \mathrm{~mL}$ sorting buffer for sorting. iPS $\left(\mathrm{PI}^{-} \mathrm{GFP}^{+}\right)$, NPAD $\left(\mathrm{PI}^{-} \mathrm{GFP}^{+}\right)$, and GFP-negative $\left(\mathrm{PI}^{-} \mathrm{GFP}^{-}\right)$cells were sorted on a fluorescence-activated cell sorter (FACS; BD FACSAria ${ }^{\mathrm{TM}} \mathrm{III}, \mathrm{BD}$ ). Sorted cells were used for morphological analysis, growth rate and colony formation assays.

\section{Growth rate}

NPAD and GFP-negative cells were seeded at $1.5 \times 10^{5}$ cells/well in six wells of a 48-well plate seeded with MEFs, and dispersed in three wells after $24 \mathrm{~h}$ and $96 \mathrm{~h}$. The Automated Cell Counter (TC 20, Bio-Rad) was used to determine cell numbers. For culturing, we used the feeder cell culture medium. 


\section{Colony formation assay}

Equal amounts of $2 \times$ ES cell culture medium and 2\% agar (Difco Agar Noble, BD) were mixed $(2 \mathrm{~mL})$, poured into 6-cm dish, and allowed to solidify (bottom agar). The same culture medium and 1\% agar seeded with iPS or NPAD cells at $10^{5}$ cells/dish were mixed in equal amounts, and 2-mL volumes of this mixture were layered over the bottom agar. Furthermore, $2 \mathrm{~mL}$ of feeder cell medium was added and the cells were cultured for 20 days.

\section{Morphological analysis}

For living cells, iPS and NPAD cells were detected and observed using a confocal laser scanning microscope (FV 10i; Olympus, Japan) with or without GFP fluorescence as an indicator. iPS and NPAD cells were photographed under the confocal laser scanning microscope, and their morphological features were determined using the image analysis software ImageJ [10]. Features analyzed included the nuclear major axis, nuclear minor axis, nuclear area, cytoplasmic major axis, cytoplasmic minor axis, cytoplasmic area, and nucleo-cytoplasmic (N/C) ratio. 
In addition, similar morphological analysis was performed on cells subjected to Papanicolaou (Pap.) staining and May-Grunwald's Giemsa (Giemsa) staining. In this case, the cells were separated by FACS depending on GFP fluorescence. Obtained cells were smeared, fixed, and then stained.

Statistical analysis

Statistically significant differences between groups $(\mathrm{p}<0.05)$ were determined using the Mann-Whitney $U$-test. 


\section{Results}

Cell sorting

We were able to sort iPS $\left(\mathrm{PI}^{-} \mathrm{GFP}^{+}\right), \operatorname{NPAD}\left(\mathrm{PI}^{-} \mathrm{GFP}^{+}\right)$, and GFP-negative ( $\mathrm{PI}^{-} \mathrm{GFP}^{-}$) cells (Fig. 3).

\section{Growth rate}

We considered the number of cells at $24 \mathrm{~h}$ as $100 \%$, and NPAD cell number at $96 \mathrm{~h}$ was approximately eight-fold higher, while that of the GFP-negative cells was shown to be increased approximately two-fold (Fig. 4).

Colony formation assay

Colony formation assay results showed that four colonies were formed following the seeding of NPAD cells (Fig. 5A), but a large number of colonies were formed following the seeding of iPS cells (Fig. $5 B)$. 
Analysis of live cells

According to the results of confocal laser scanning microscope analysis, iPS cells exhibited round or oval cytoplasms and nuclei (Fig. 6A). The nuclei of iPS cells tended to be eccentric, and one or more nucleoli were observed in the nucleus (Fig. 6B). There were regions with granule-like structures in the cytoplasms of iPS cells, while other regions in the cytoplasm were unstructured (Fig. 6C). Some iPS cells had round inclusion-like structures in the cytoplasm. According to the fluorescence images, iPS cells were Nanog-GFP-positive in both the cytoplasm and nucleus (Fig. 6A'-C').

NPAD cells also exhibited round or oval cytoplasms and nuclei (Fig. 7A). The nuclei of NPAD cells tended to be eccentric, and one or more nucleoli were observed in the nucleus (Fig. 7A). NPAD cells showing round inclusion-like structures in the cytoplasm were observed (Fig. 7A). The nuclei of NPAD cells were brighter than the cytoplasm, and almost no structures other than the nucleolus was found in the nucleus (Fig. 7B). In addition, some NPAD cells had granule-like structures, but the rest of the cytoplasm was unstructured (Fig. 7B). According to fluorescence 
imaging, NPAD cells were Nanog-GFP-positive in both the cytoplasm and nucleus (Fig. 7A'-C').

In addition, extremely small cells were observed among NPAD cells (Fig. 7C). These small cells had round cytoplasms and nuclei (Fig. 7C). The interior of the nucleus was pyknotic, and the internal structures were unclear (Fig. 7C). In fluorescence images, small cells were Nanog-GFPpositive in both the cytoplasm and nucleus (Fig. 7C').

According to analysis by ImageJ, iPS cells exhibited an average nuclear major axis of $10 \pm 2 \mu \mathrm{m}$ (mean \pm standard deviation), nuclear minor axis of $9 \pm 1 \mu \mathrm{m}$, nuclear area of $76 \pm 26 \mu \mathrm{m}^{2}$, cytoplasm major axis of $13 \pm 2 \mu \mathrm{m}$, cytoplasm minor axis of $12 \pm 1 \mu \mathrm{m}$, cytoplasm area of $120 \pm 33 \mu \mathrm{m}^{2}$, and N/C ratio of $63 \pm 7 \%$ (Table 1). In contrast, NPAD cells exhibited an average nuclear major axis of $9 \pm 2 \mu \mathrm{m}$, nuclear minor axis of $8 \pm 2 \mu \mathrm{m}$, nuclear area of $62 \pm 28 \mu \mathrm{m}^{2}$, cytoplasm major axis of $12 \pm 2 \mu \mathrm{m}$, cytoplasm minor axis of $11 \pm 1 \mu \mathrm{m}$, cytoplasm area of $99 \pm$ $28 \mu \mathrm{m}^{2}$, and $\mathrm{N} / \mathrm{C}$ ratio of $60 \pm 14 \%$ (Table 1).

Following statistical analysis, statistically significant differences between iPS and NPAD cells were observed in terms of nuclear area, 
cytoplasm area, nuclear major axis, nuclear minor axis, cytoplasm minor axis, and N/C ratio (Table 1). Furthermore, NPAD cells were significantly smaller than iPS cells (Fig. 8).

Analysis of Pap.-stained cells

According to the microscopic analysis of Pap.-stained cells, iPS cells exhibited round or oval cytoplasms that were moderately to highly stained light green, with round or oval nuclei with euchromatic structures. There were like bare nuclei cells (Fig. 9A). The nuclei of iPS cells tended to be eccentric, the nuclear margins were clear, and one or more nucleoli were found in the nucleus (Fig. 9A). In the cytoplasms of some iPS cells, round inclusion-like structures that were moderately to highly stained light green were observed (Fig. 9A).

Similarly, NPAD cells exhibited round or oval cytoplasms that were moderately to highly stained light green, with round or oval nuclei (Fig. 9B). The nuclei of NPAD cells tended to be eccentric, the nuclear margins were clear, and one or more nucleoli were observed in the nucleus (Fig. 9B). Some NPAD cells had round inclusion-like structures 
that were moderately to highly stained light green in the cytoplasm (Fig. 9B). In addition, some small NPAD cells were observed (Fig. 9B). Small cells were characterized by round cytoplasms moderately to highly stained light green with pyknotic nuclei (Fig. 9B).

Following analysis by ImageJ, iPS cells had a nuclear major axis of $10 \pm 2 \mu \mathrm{m}$ (mean \pm standard deviation), nuclear minor axis of $9 \pm 1 \mu \mathrm{m}$, nuclear area of $75 \pm 23 \mu \mathrm{m}^{2}$, cytoplasm major axis of $12 \pm 2 \mu \mathrm{m}$, cytoplasm minor axis of $10 \pm 2 \mu \mathrm{m}$, cytoplasm area of $97 \pm 31 \mu \mathrm{m}^{2}$, and N/C ratio of $78 \pm 10 \%$ (Table 2).

In contrast, NPAD cells had a nuclear major axis of $8 \pm 2 \mu \mathrm{m}$, nuclear minor axis of $7 \pm 1 \mu \mathrm{m}$, nuclear area of $46 \pm 19 \mu \mathrm{m}^{2}$, cytoplasm major axis of $10 \pm 1 \mu \mathrm{m}$, cytoplasm minor axis of $9 \pm 1 \mu \mathrm{m}$, cytoplasm area of $71 \pm 21 \mu \mathrm{m}^{2}$, and N/C ratio of $64 \pm 17 \%$ (Table 2). There were statistically significant differences in the areas of the nucleus and cytoplasm between iPS and NPAD cells, in addition to the nucleus and cytoplasm major axis, minor axis, and N/C ratio (Table 2). Furthermore, NPAD cells were significantly smaller than iPS cells (Fig. 8). 
Analysis of Giemsa-stained cells

According to microscopic analysis of Giemsa-stained cells, iPS cells exhibited round or oval cytoplasms that were basophilically stained and had round or oval nuclei with fine granular chromatin (Fig. 10A). The nuclei of iPS cells tended to be eccentric, the nuclear margins were clear, and one or more nucleoli were observed in the nuclei (Fig. 10A). In addition, perinuclear haloes were observed in iPS cells (Fig. 10A).

NPAD cells exhibited round or oval cytoplasms that were basophilically stained, and the nuclei had fine granular chromatin (Fig. 10B). The nuclei of NPAD cells tended to be eccentric, the nuclear margins were clear, and one or more nucleoli were observed in the nuclei (Fig. 10B). Perinuclear haloes were also observed in NPAD cells (Fig. 10B). In addition, small cells were observed among the population of NPAD cells (Fig. 10B). Small cells exhibited basophilic staining of the cytoplasm and pyknotic nuclei (Fig. 10B).

Analysis by ImageJ indicated that iPS cells had a nuclear major axis of $14 \pm 2 \mu \mathrm{m}$ (mean \pm standard deviation), nuclear minor axis of $12 \pm 2$ $\mu \mathrm{m}$, nuclear area of $127 \pm 43 \mu \mathrm{m}^{2}$, cytoplasm major axis of $17 \pm 3 \mu \mathrm{m}$, 
cytoplasm minor axis of $14 \pm 3 \mu \mathrm{m}$, cytoplasm area of $190 \pm 66 \mu \mathrm{m}^{2}$, and N/C ratio of $68 \pm 8 \%$. NPAD had a nuclear major axis of $14 \pm 3 \mu \mathrm{m}$, nuclear minor axis of $11 \pm 2 \mu \mathrm{m}$, nuclear area of $124 \pm 43 \mu \mathrm{m}^{2}$, cytoplasm major axis of $17 \pm 2 \mu \mathrm{m}$, cytoplasm minor axis of $14 \pm 3 \mu \mathrm{m}$, cytoplasm area of $184 \pm 56 \mu \mathrm{m}^{2}$, and N/C ratio of $67 \pm 12 \%$. Results for iPS and NPAD cells were significantly different in terms of nuclear area, nuclear major axis, nuclear minor axis, cytoplasm major axis, and cytoplasm minor axis (Table 3). Furthermore, the nuclei of NPAD cells were significantly smaller than those of iPS cells (Fig. 8). 


\section{Discussion}

iPS cells are pluripotent stem cells that are able to differentiate into various cell types constituting the different tissues of the body, and they possess self-renewal ability. iPS cells that can regenerate and treat the damaged organs and cells of patients are expected to be useful to the field of regenerative medicine.

However, iPS cells form malignant immature teratomas after transplantation into animals ${ }^{5)}$. When iPS cells are clinically applied, they are used after differentiation induction into target cell types, but if undifferentiated cells remain, they form teratomas after transplantation into animals as well ${ }^{5-7)}$. In particular, we reported in a previous study that tumors formed by iPS cells or cells derived from iPS cells were malignant immature teratomas ${ }^{5)}$. It has been suggested that NPAD cells are responsible for this malignant immature teratoma formation ${ }^{5)}$.

In this study, NPAD cells were shown to have anchorage-independent growth, and their growth rate was confirmed to be significantly higher than that of the GFP-negative cells, indicating that NPAD cells cause tumorigenesis. Therefore, before cells derived from iPS cells can be 
applied in regenerative medicine, it is necessary to remove NPAD cells, including residual iPS cells ${ }^{5)}$, to remove the cause of malignant immature teratoma formation. In addition, when cells derived from iPS cells are applied in regenerative medicine, live cells must be used.

In this study, we revealed the morphological features of live iPS and NPAD cells. Based on our results, isolated, live iPS cells have round or oval cytoplasms and nuclei. In addition, there are regions of the cytoplasm with granule-like structures, but most of the cytoplasm is unstructured. Most of the insides of the nuclei were bright without a nucleolus. In addition, Pap.-stained iPS cells were bare nucleus-like cells with round or oval cytoplasms and euchromatic nuclei. Giemsa-stained iPS cells had basophilic round or oval cytoplasms and fine granular chromatin. The observations derived from stained cells were therefore similar to those of live iPS cells.

According to Zeuschner et al., iPS cells in colonies cultured with MEFs exhibited poor intracellular organelles as compared with MEFs according to analysis using an electron microscope ${ }^{11)}$. Furthermore, they reported that iPS and ES cells had euchromatin and clear nucleoli ${ }^{11,12)}$. 
We revealed that isolated, live NPAD cells exhibited round or oval cytoplasms and nuclei. In addition, granule-like structures appeared in some cytoplasmic regions, while most other regions were unstructured. Regarding the nucleus, it had not any more structure except for clear nucleoli.

In addition, small cells were observed among NPAD cells. These small cells exhibited round cytoplasms and nuclei. Virant-Klunn et al. reported that pluripotent stem cells in the human ovarian surface epithelium were small and round $(2-4 \mu \mathrm{m})$. They expressed SSEA-4, OCT-4, NANOG, SOX-2, and c-KIT as embryonic markers and formed embryoid-like structures in vitro ${ }^{13)}$. Zuba-Surma et al. reported that SSEA-1, Oct-4, Nanog, and Rex-1-expressing stem cells derived from mouse bone marrow were extremely small $(3.63 \pm 0.09 \mu \mathrm{m}){ }^{14)}$. These reports support our evidence for the presence of small cells among NPAD cells.

As mentioned above, the morphological analysis in this study is applicable to human iPS cells, the genetic alteration of which presents ethical challenges. We observed that cells with different sizes can be 
observed in the population of NPAD cells, and these were shown to be considerably different morphologically from the iPS cells. The results of this study, showing that the removal of the pluripotent stem cells is possible with morphological techniques, may help improve the safety of iPS cell application in regenerative medicine.

Currently, methods for removing human pluripotent stem cells (hPSCs) that remain after differentiation induction include the introduction of suicide genes into hPSCs or the selective killing of hPSCs using cytotoxic antibodies, chemical inhibitors, or specific antibodies against hPSCs ${ }^{15-18)}$. However, these methods suffer from several issues with regards to specificity, efficacy, and safety for use in cell therapy for humans.

Our morphological study reveals the possibility of detecting and removing NPAD cells without the cell damage caused by genetic modification. Therefore, we provide a possible approach for using hPSCs while overcoming the ethical problems involving genetic modification and safety problems involving drugs used to kill hPSCs. 
Our findings therefore have important implications for the realization of regenerative medicine using iPS cells. 


\section{Acknowledgements}

Firstly, I would like to express my sincere gratitude to my supervisor Professor Eiji Ohno for the continuous support of my Ph.D study and related research. His guidance helped me in all the time of research and writing of this thesis.

I am also deeply grateful to Professor Setsuyo Ohno, Junya Mitoma, Tomoyuki Miyamoto, Hiromasa Yakusiji and Makoto Nishimori for their insightful comments and encouragement, but also for the hard question which incented me to widen my research from various perspectives.

Finally, I also grateful to the members of Department of Medical Life Science, Faculty of Medical Bioscience, Kyushu University of Health and Welfare. 


\section{Author Disclosure Statement}

No competing financial interests exist. 


\section{References}

1)Evans MJ and Kaufman MH. Establishment in culture of pluripotential cells from mouse embryos. Nature 1981; 292:154-156.

2)Thomson JA, Itskovitz-Eldor J, Shapiro SS, et al. Embryonic stem cell lines derived from human blastocysts. Science 1998; 282:1145-1147.

3)Takahashi K and Yamanaka S. Induction of pluripotent stem cells from mouse embryonic and adult fibroblast cultures by defined factors. Cell 2006; 126:663-676.

4)Takahashi K, Tanabe K, Ohnuki M, et al. Induction of pluripotent stem cells from adult human fibroblasts by defined factors. Cell 2007; $131: 861-872$.

5)Nishimori M, Yakushiji H, Mori M, et al. Tumorigenesis in cells derived from induced pluripotent stem cells. Hum Cell 2014; 27:29-35.

6)Miura K, Okada Y, Aoi T, et al. Variation in the safety of induced pluripotent stem cell lines. Nat Biotechnol 2009; 27:743-745.

7)Fu W, WangSJ, Zhou GD, et al. Residual undifferentiated cells during differentiation of induced pluripotent stem cells in vitro and in vivo.

Stem Cells Dev 2011; 21:521-529. 
8)Okita K, Ichisaka $\mathrm{T}$ and Yamanaka S. Generation of germline-competent induced pluripotent stem cells. Nature 2007; 448:313-317.

9)Silva J, Nichols J, Theunissen TW, et al. Nanog is the gateway to the pluripotent ground state. Cell 2009; 138:722-737.

10)Schneider CA, RasbandWS andEliceiri KW. NIH Image to ImageJ: 25 years of image analysis. Nat Methods 2012; 9:671-675.

11)Zeuschner D, Mildner K, Zaehres H, et al. Induced pluripotent stem cells at nanoscale. Stem Cells Dev 2010; 19:615-620.

12)Courtot AM, Magniez A, Oudrhiri N, et al. Morphological analysis of human induced pluripotent stem cells during induced differentiation and reverse programming. BioRes Open Access 2014; 3:206-216.

13)Virant-Klun I, Rozman P, Cvjeticanin B, et al. Parthenogenetic embryo-like structures in the human ovarian surface epithelium cell culture in postmenopausal women with no naturally present follicles and oocytes. Stem Cells Dev 2009; 18:137-149.

14)Zuba-Surma EK, Kucia M, Abdel-Latif A, et al. Morphological characterization of very small embryonic-like stem cells (VSELs) by 
ImageStream system analysis. J CellMol Med 2008; 12:292-303.

15)Schuldiner M, Itskovitz-Eldor J andBenvenisty N. Selective ablation of human embryonic stem cells expressing a "suicide" gene. Stem Cells $2003 ; 21: 257-265$.

16)Tang C, Lee AS, Volkmer JP, et al. An antibody against SSEA-5 glycan on human pluripotent stem cells enables removal of teratoma-forming cells. NatBiotechnol 2011; 29:829-834.

17)Ben-David U, GanQF, Golan-Lev T, et al. Selective elimination of human pluripotent stem cells by an oleate synthesis inhibitor discovered in a high-throughput screen. Cell Stem Cell 2013; 12:167-179. 18)Ben-David U, Nudel N and Benvenisty N. Immunologic and chemical targeting of the tight-junction protein Claudin- 6 eliminates tumorigenic human pluripotent stem cells. NatCommun 2013; 4:1992. 


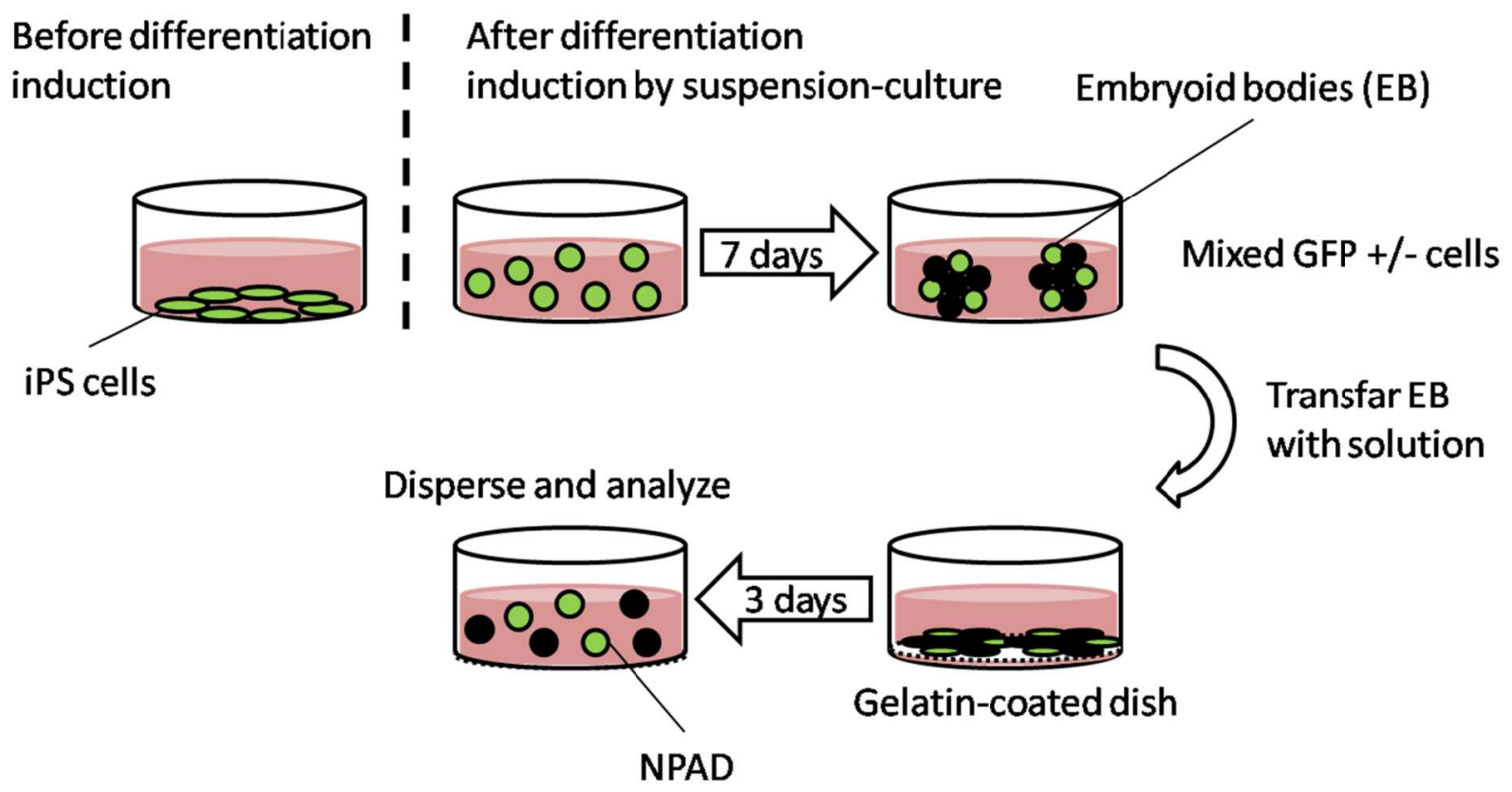

Fig. 1. Induction of induced pluripotent stem (iPS) cell differentiation. iPS cells dispersed with trypsin were seeded onto a low-adhesion culture dish and cultured, using the feeder cell culture medium. On day 7 after the seeding, the formed embryoid bodies were transferred to gelatin-coated cell culture dishes, where they were cultured for 3 days. Cells expressing Nanog-green fluorescent protein (GFP) for a total of 10 days were defined as Nanog-GFP-positive after differentiation (NPAD) cells, which were dispersed by enzyme and analyzed. 

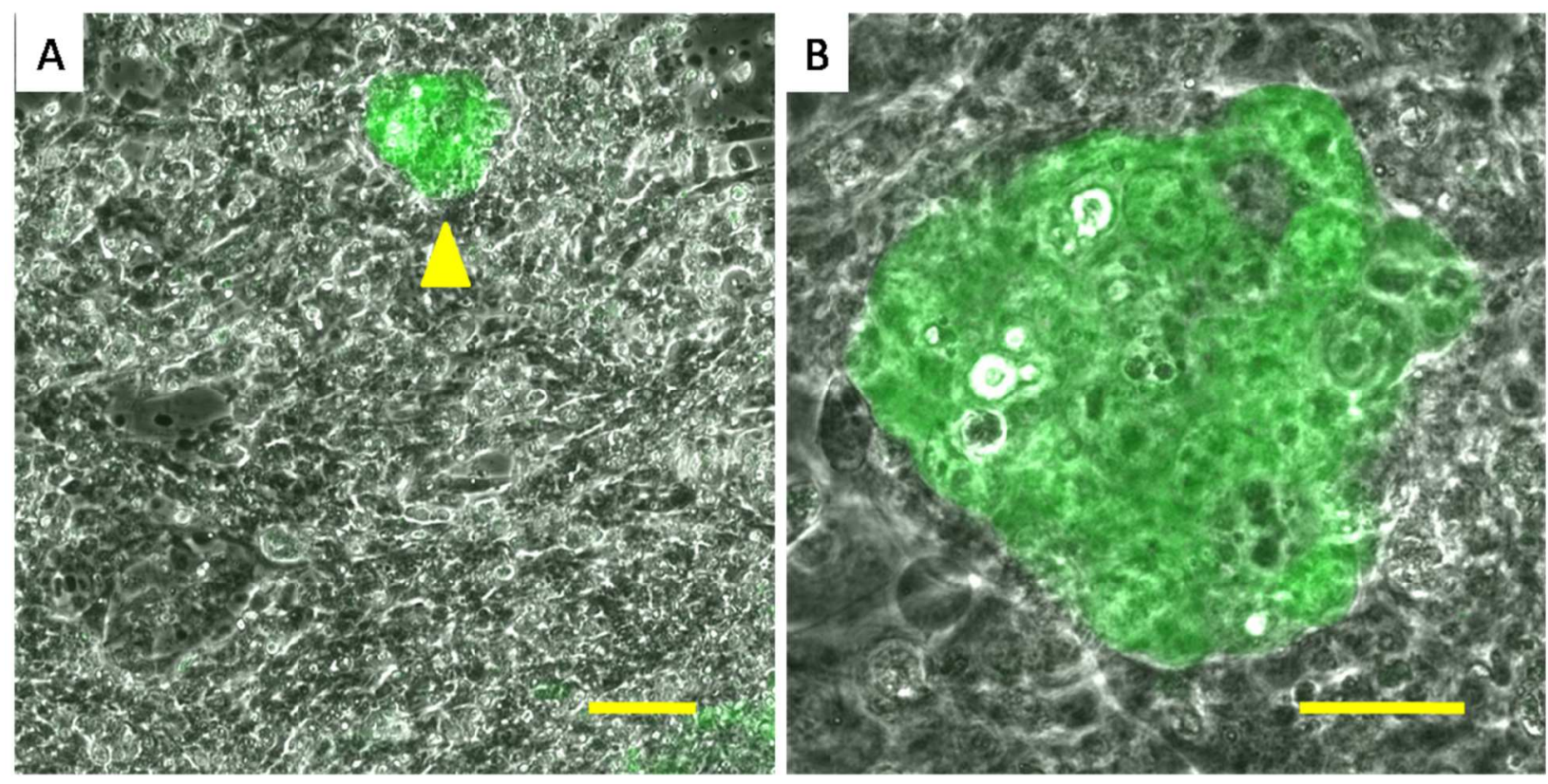

Fig. 2. Nanog-GFP-positive after differentiation (NPAD) cells among Nanog-green fluorescent protein (GFP)-negative cells derived from the embryoid bodies. (A) Following the differentiation induction, NPAD cells were observed among the GFP-negative cells (yellow arrowhead). Magnification, 10x; Scale bar, $50 \mu \mathrm{m}$. (B) NPAD cell presented in (A). Magnification, 60×; Scale bar, $20 \mu \mathrm{m}$; Green, GFP fluorescence. 


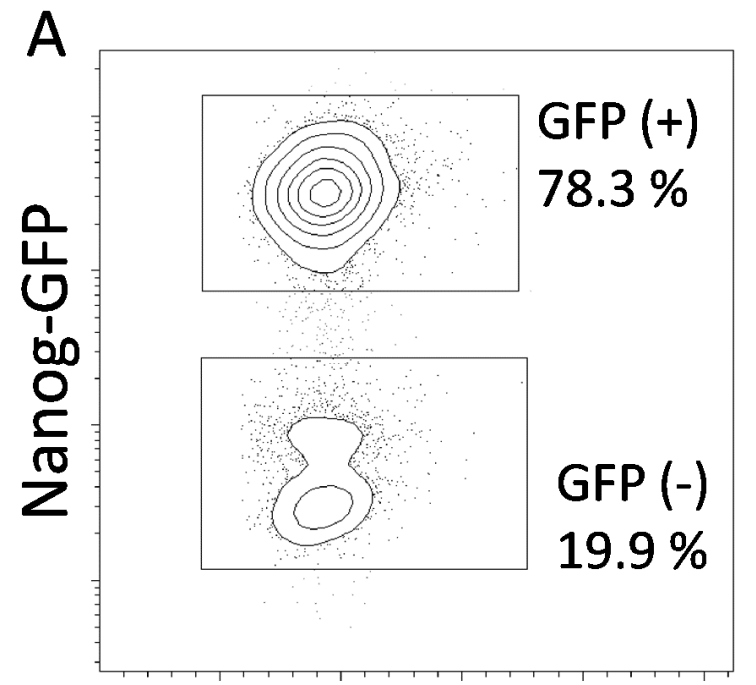

FSC (forward scatter)

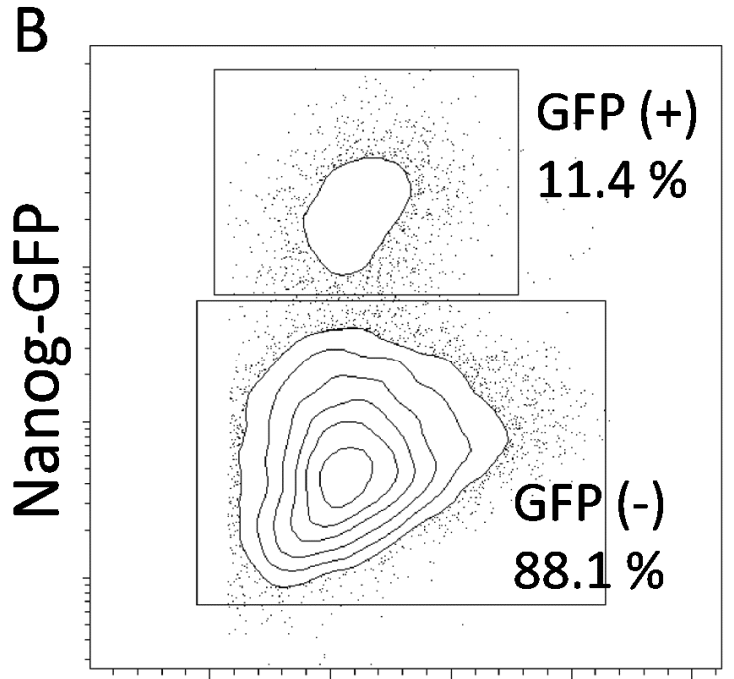

FSC (forward scatter)

Fig. 3. Isolation of induced pluripotent stem (iPS), Nanog-GFP-positive after differentiation (NPAD) and green fluorescent protein (GFP)-negative cells using a fluorescence-activated cell sorter. (A) iPS cells were sorted based on Nanog-GFP expression. iPS cells expressed Nanog-GFP. (B) NPAD and GFP-negative cells were sorted based on Nanog-GFP expression. NPAD cells expressed Nanog-GFP but GFP-negative cells didn't express Nanog-GFP. 
1200

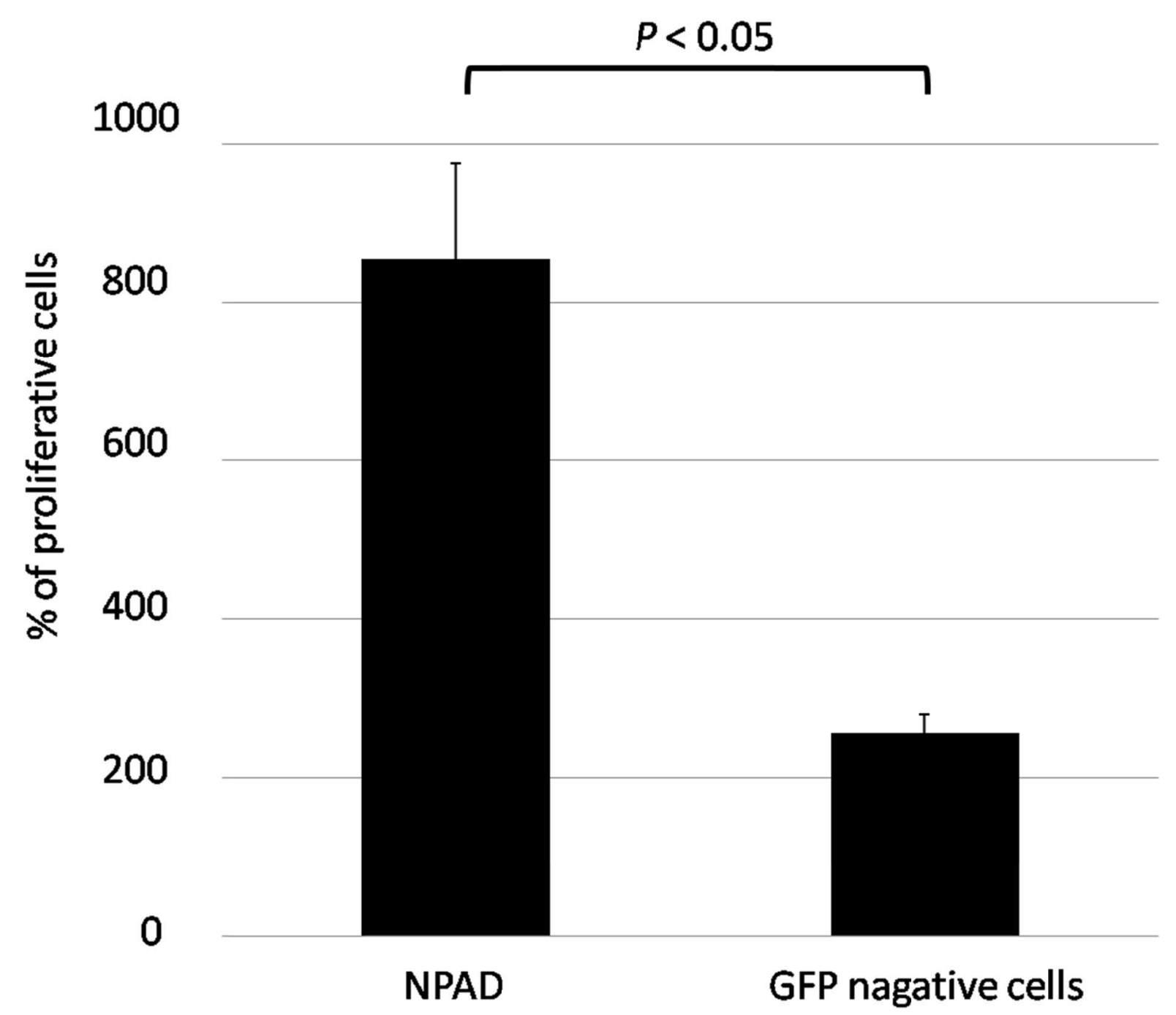

Fig. 4. Growth rate of Nanog-GFP-positive after differentiation (NPAD) and green fluorescent protein (GFP)-negative cells. y-axis, the percentage of cells at $96 \mathrm{~h}$, compared with that at $24 \mathrm{~h}(100 \%)$.

NPAD cells grew faster than GFP-negative cells. 

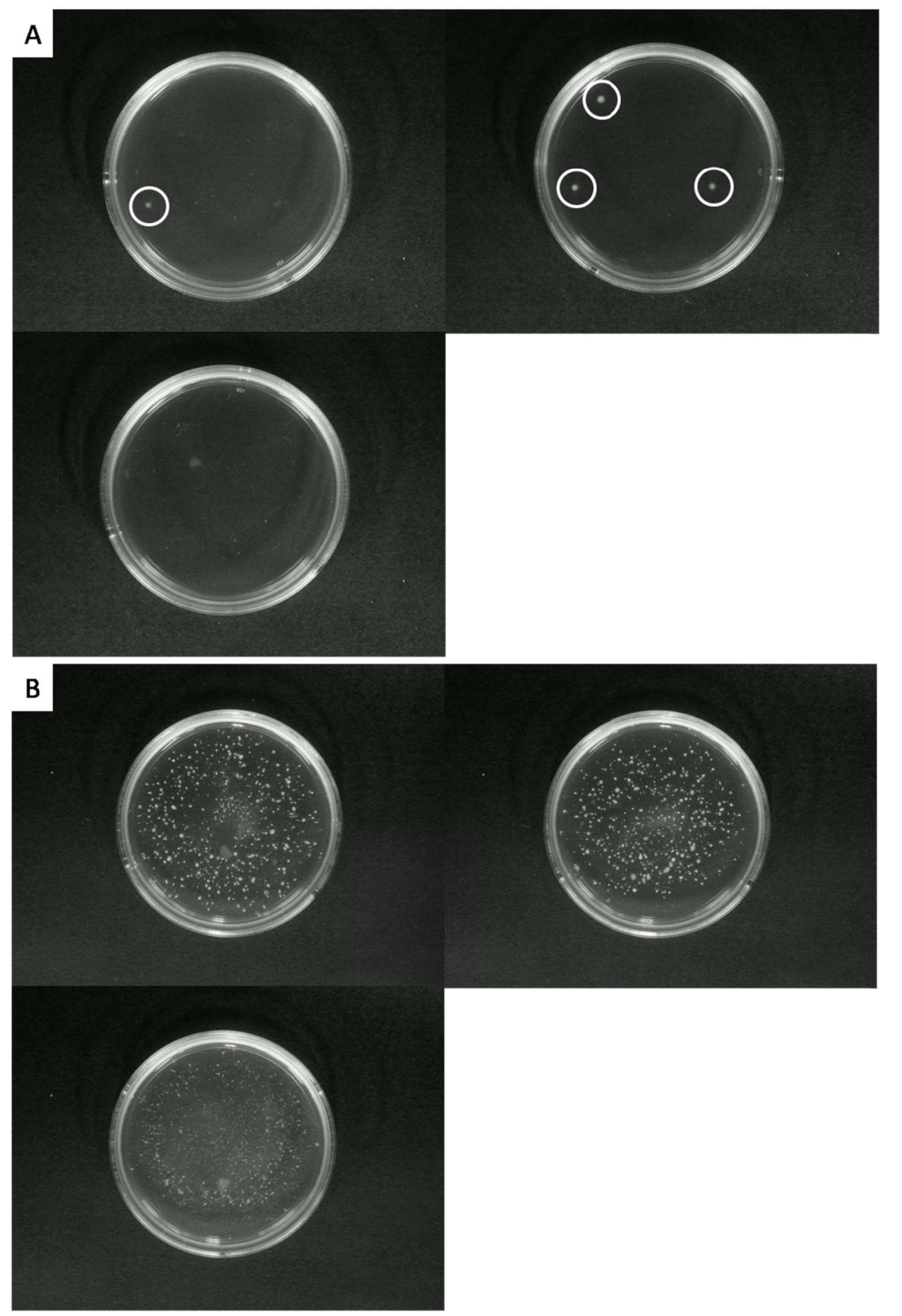

Fig. 5. Colony formation of Nanog-GFP-positive after differentiation (NPAD) cells and induced pluripotent stem (iPS) cells. (A) Plates seeded with NPAD cells. (B) Colony formation in plates seeded with iPS cells. 
NPAD cells were shown to have anchorage-independent growth. 

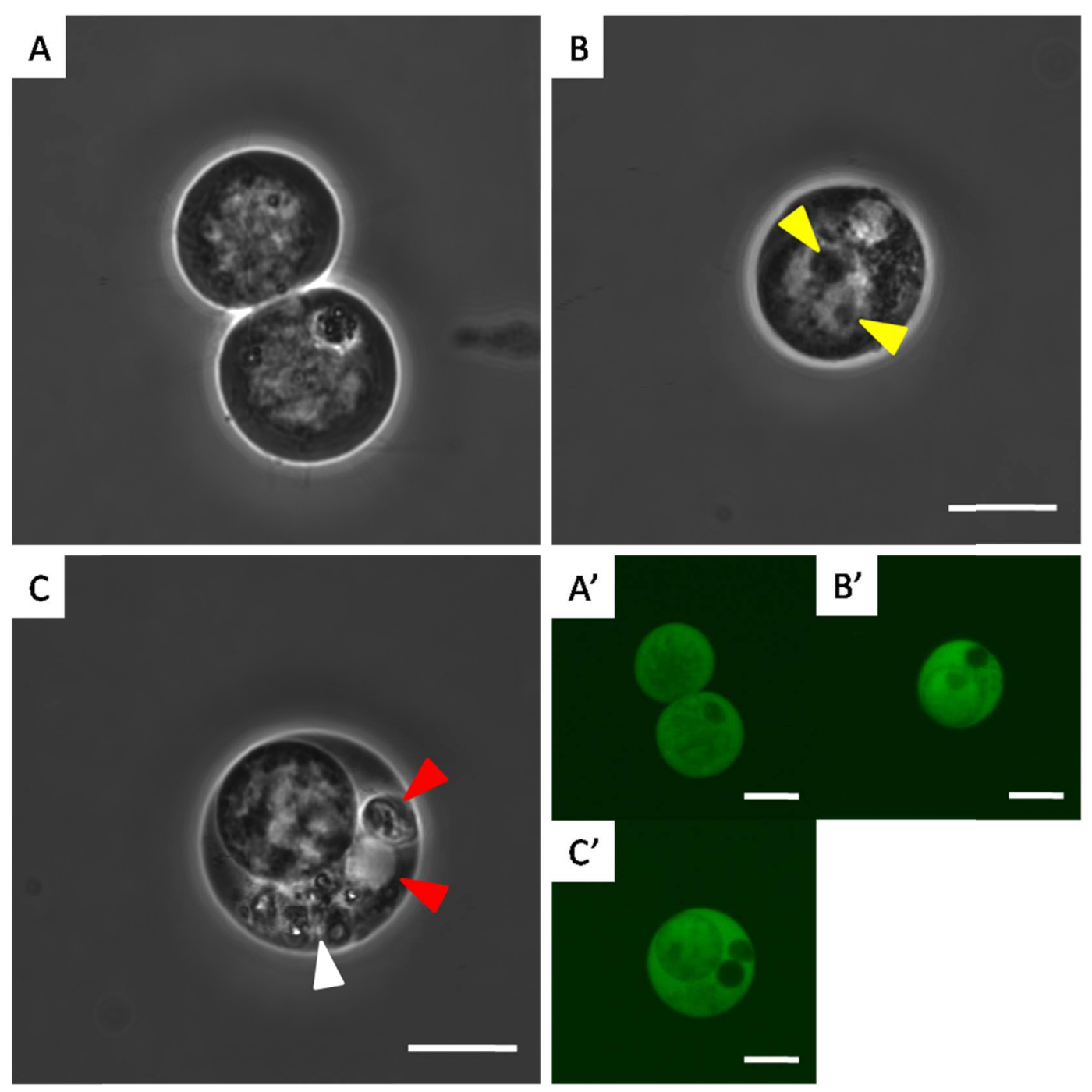

Fig. 6. Viable induced pluripotent stem (iPS) cells. (A) iPS cells with round or oval cytoplasms and nuclei. (B) Nuclei tended to be eccentric, with one or more prominent nucleoli (yellow arrowheads). (C) Regions with granule-like structures were observed (white arrowhead). Round inclusion-like structures were observed in the cytoplasm (red arrowheads). ( $\left.\mathrm{A}^{\prime}-\mathrm{C}^{\prime}\right)$ Fluorescence images of $(\mathrm{A}-\mathrm{C})$. Magnification, $60 \times ;$ Scale bar, $10 \mu \mathrm{m}$. 


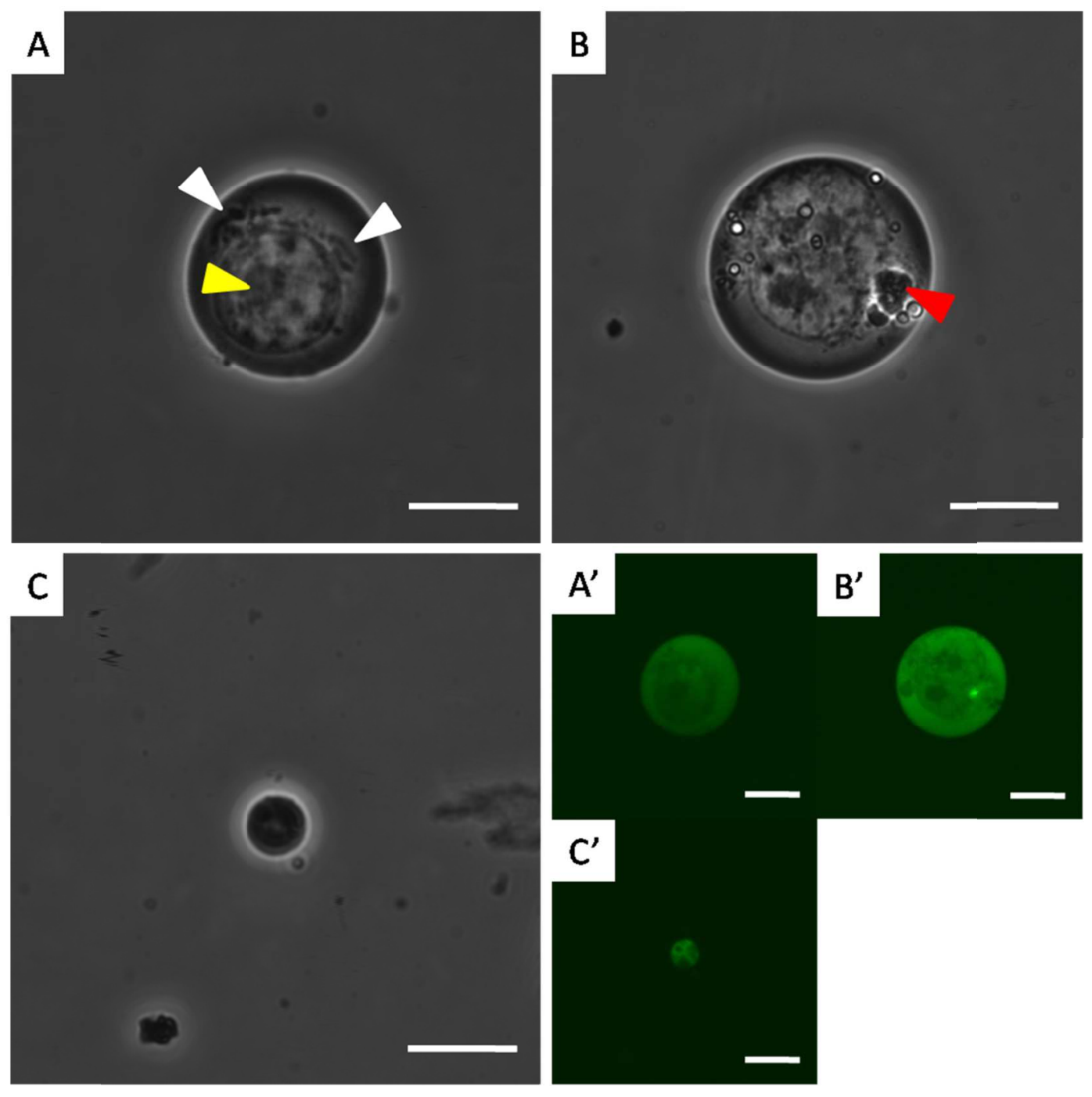

Fig.7. Viable Nanog-GFP-positive after differentiation (NPAD) cells. (A) NPAD cells with round or oval cytoplasms and nuclei, which tended to be eccentric, with one or more prominent nucleoli (yellow arrowhead). Regions with granule-like structures were observed in the cytoplasm (white arrowheads), while other regions were unstructured. (B) Round inclusion-like structures were observed in the cytoplasm (red arrowhead).

(C) Small cells were observed. $\left(\mathrm{A}^{\prime}-\mathrm{C}^{\prime}\right)$ Fluorescence images 
corresponding to (A-C). Magnification, 60x ; Scale bar, $10 \mu \mathrm{m}$. 
A : Nucleus area
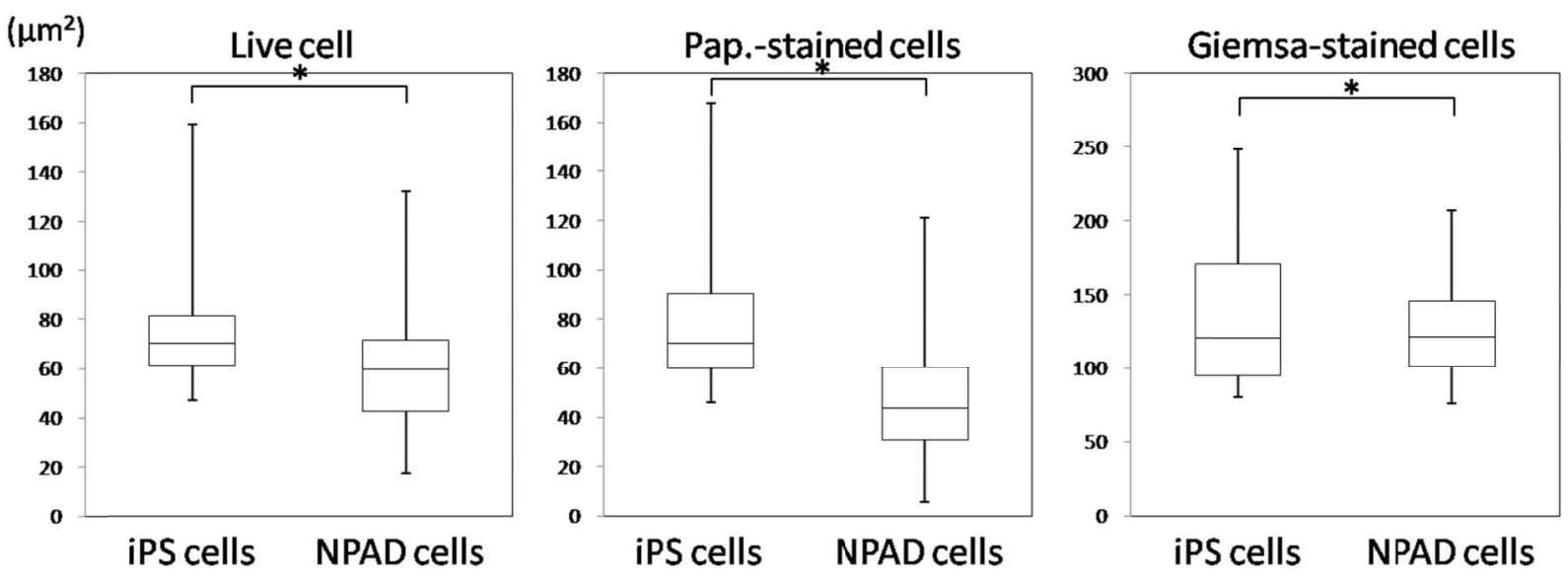

B : Cytoplasm area
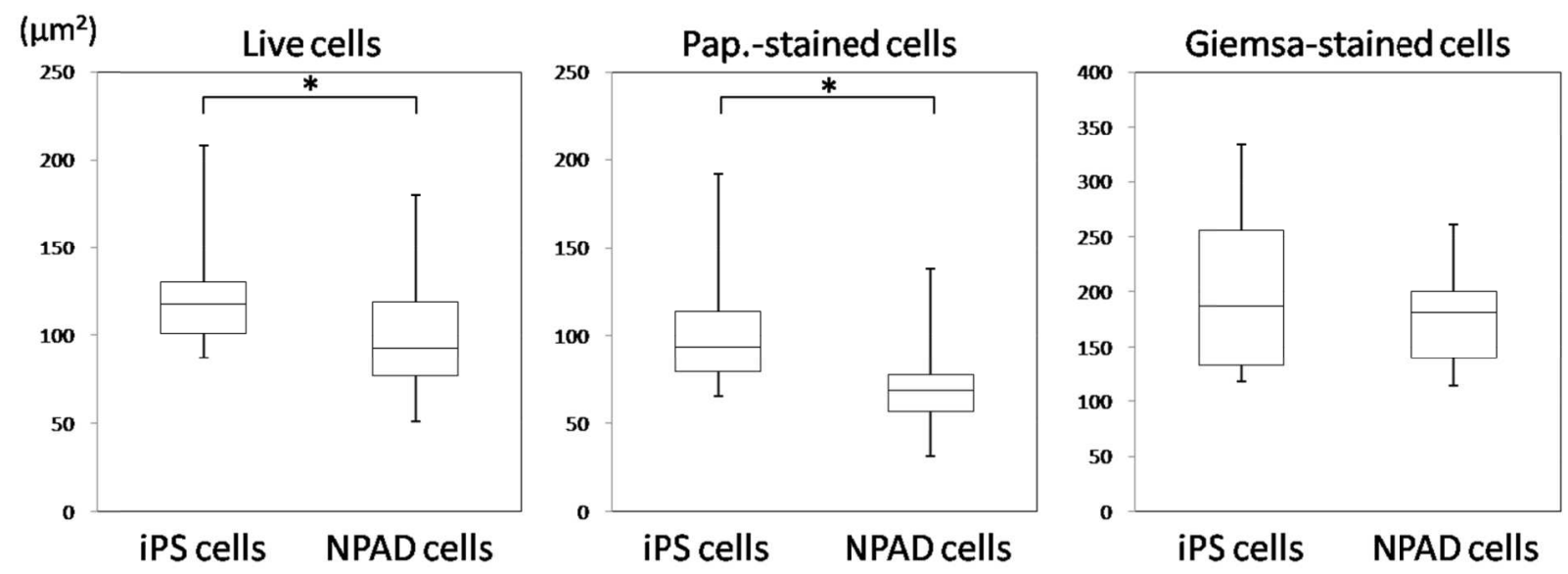

Fig. 8. Distributions of the nuclear and cytoplasmic areas in induced pluripotent stem (iPS) and Nanog-GFP-positive after differentiation (NPAD) cells. (A) NPAD and iPS cell nuclei in live, Pap-stained, and Giemsa-stained cells. (B) NPAD and iPS cell cytoplasmic areas in live and Pap-stained cells.* $\mathrm{p}<0.05$ (Mann-Whitney $U$-test). 

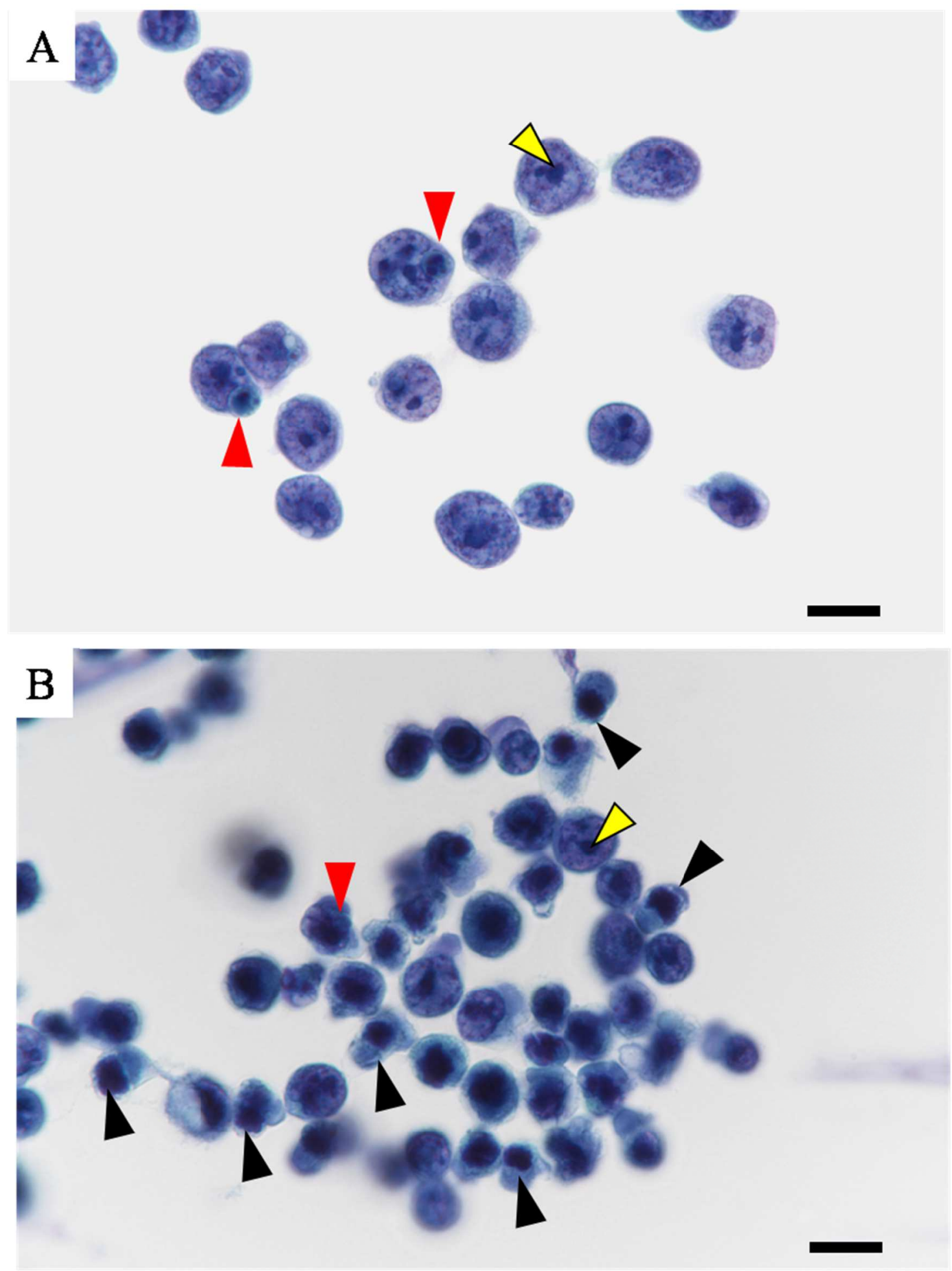

Fig. 9. Papanicolaou-stained induced pluripotent (iPS) and Nanog-

GFP-positive after differentiation (NPAD) cells. (A) iPS cells with bare 
nuclei and round or oval cytoplasms, moderately to highly stained light green, and the euchromatic chromatin network. Nuclei tended to be localized, and one or more nucleoli were observed in the nuclei (yellow arrowhead). Round inclusion-like structures, stained moderate-to-high light green, were observed in the cytoplasm (red arrowheads). (B) NPAD cells with round or oval cytoplasms, moderately to highly stained light green. Nuclei tended to be eccentric, and one or more nucleoli were observed in the nucleus (yellow arrowhead). Round inclusion-like structures that were moderately to highly stained light green were observed in the cytoplasm (red arrowheads). Small cells were observed (black arrowheads), with round or oval cytoplasms, moderately to highly stained light green with pyknotic nuclei. Magnification,100x ; Scale bar, $10 \mu \mathrm{m}$. 

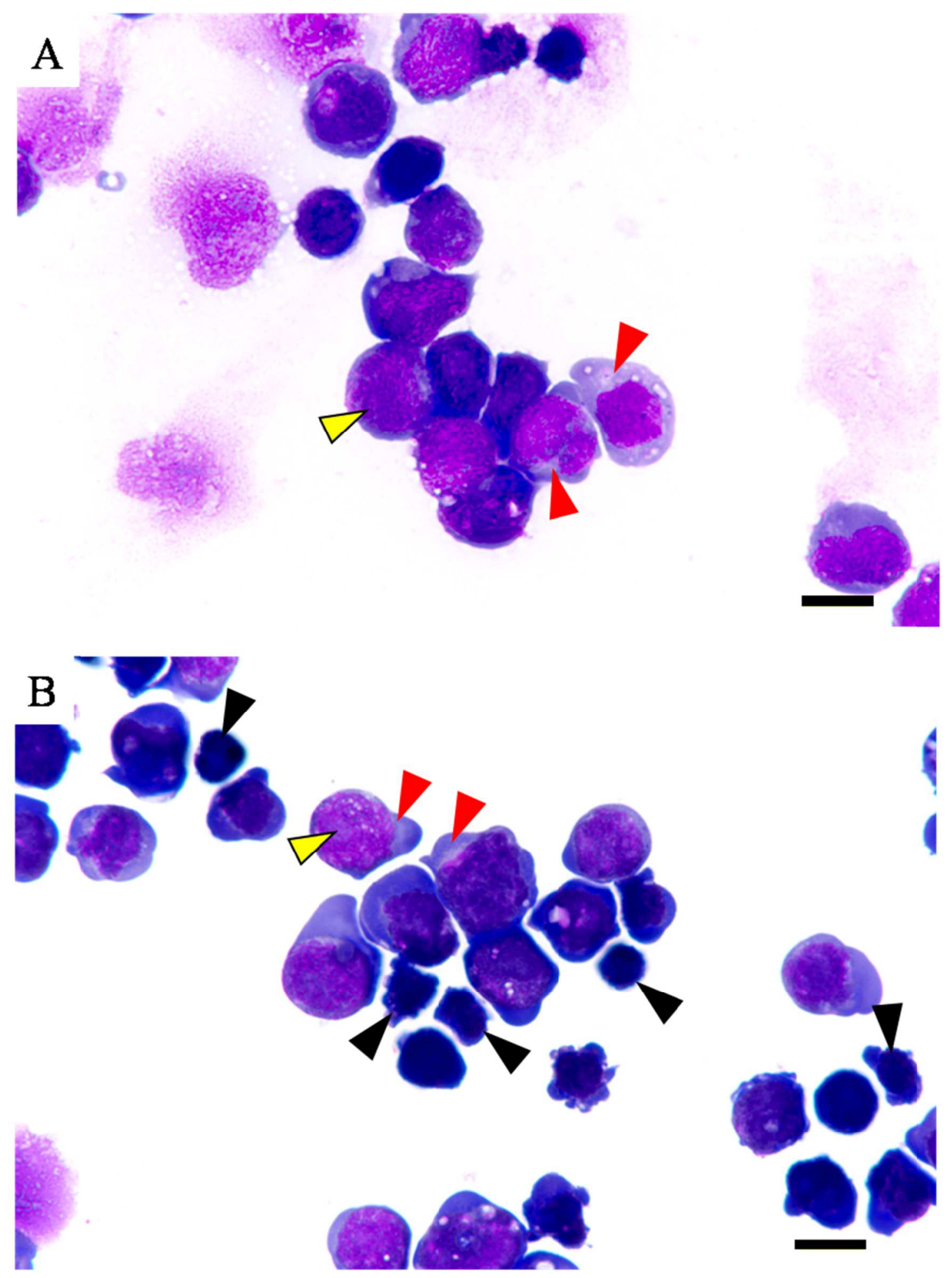

Fig. 10. Giemsa-stained induced pluripotent stem (iPS) and Nanog-

GFP-positive after differentiation (NPAD) cells. (A) iPS cells with round 
or oval cytoplasms, basophilically stained, with round or oval nuclei with fine granular chromatin. The nuclei tended to be eccentric, the nuclear margins were clear, and one or more nucleoli were observed in the nucleus (yellow arrowhead). Perinuclear halos were observed (red arrowheads). (B) NPAD cells with basophilic round or oval cytoplasms and fine granular nuclei. The nuclei tended to be eccentric, and one or more nucleoli were observed in the nuclei (yellow arrowhead). Perinuclear halos were observed (red arrowheads). Small cells were observed (black arrowheads), with basophilic cytoplasms and pyknotic nuclei.Magnification, 100x; Scale bar, $10 \mu \mathrm{m}$. 
Table 1. Size of live iPS and NPAD cells.

Nucleus

\begin{tabular}{|c|c|c|c|c|c|}
\hline & Major axis $(\mu \mathrm{m})$ & Minor axis $(\mu \mathrm{m})$ & Area $\left(\mu \mathrm{m}^{2}\right)$ & & \\
\hline $\begin{array}{l}\text { iPS cells } \\
\text { NPAD }\end{array}$ & $\left.\begin{array}{c}10 \pm 2 \\
9 \pm 2\end{array}\right] *$ & $\left.\begin{array}{c}9 \pm 1 \\
8 \pm 2\end{array}\right] *$ & $\begin{array}{l}76 \pm 26 \\
62 \pm 28\end{array}$ & $\Gamma_{*}$ & \\
\hline \multicolumn{5}{|c|}{ Cytoplasm } & $\mathrm{N} / \mathrm{C}$ ratio \\
\hline & Major axis $(\mu \mathrm{m})$ & Minor axis $(\mu \mathrm{m})$ & Area $\left(\mu \mathrm{m}^{2}\right)$ & & $(\%)$ \\
\hline $\begin{array}{l}\text { iPS cells } \\
\text { NPAD }\end{array}$ & $\begin{array}{l}13 \pm 2 \\
12 \pm 2\end{array}$ & $\left.\begin{array}{c}12 \pm 1 \\
11 \pm 1\end{array}\right] *$ & $\left.\begin{array}{c}120 \pm 33 \\
99 \pm 28\end{array}\right]$ & * & $\left.\begin{array}{c}63 \pm 7 \\
60 \pm 14\end{array}\right]$ \\
\hline
\end{tabular}

${ }^{*} p<0.05$ (Mann-Whitney $U$-test), iPS; induced pluripotent stem, NPAD; Nanog-GFP-positive after differentiation induction, N/C ratio; nucleocytoplasmic ratio. 
Table 2. Size of Papanicolaou-stained iPS and NPAD cells.

\section{Nucleus}

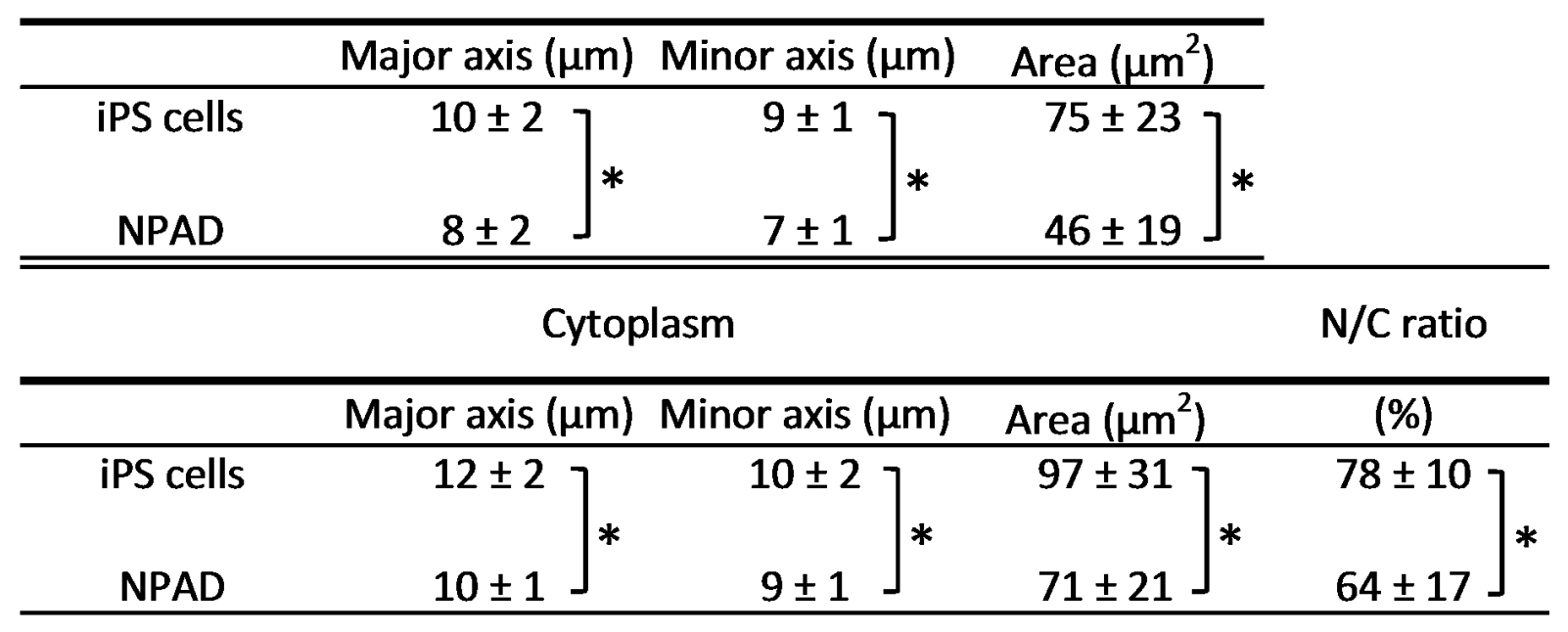

${ }^{*} p<0.05$ (Mann-Whitney $U$-test), iPS; induced pluripotent stem, NPAD; Nanog-GFP-positive after differentiation induction, $\mathrm{N} / \mathrm{C}$ ratio; nucleocytoplasmic ratio. 
Table 3. Size of May-Grunwald's Giemsa-stained iPS and NPAD cells.

Nucleus

\begin{tabular}{|c|c|c|c|}
\hline & Major axis $(\mu \mathrm{m})$ & Minor axis $(\mu \mathrm{m})$ & Area $\left(\mu \mathrm{m}^{2}\right)$ \\
\hline iPS cells & $14 \pm 2$ & $12 \pm 2$ & $127 \pm 43$ \\
\hline NPAD & $14 \pm 3$ & $11 \pm 2$ & $124 \pm 43$ \\
\hline
\end{tabular}

Cytoplasm

$\mathrm{N} / \mathrm{C}$ ratio

\begin{tabular}{ccccc}
\hline & Major axis $(\mu \mathrm{m})$ & Minor axis $(\mu \mathrm{m})$ & Area $\left(\mu \mathrm{m}^{2}\right)$ & $(\%)$ \\
\hline iPS cells & $17 \pm 3$ & $14 \pm 3$ & $190 \pm 66$ & $68 \pm 8$
\end{tabular}

NPAD $\quad 17 \pm 2$

$14 \pm 3$

$184 \pm 56$

$67 \pm 12$

${ }^{*} \mathrm{p}<0.05$ (Mann-Whitney $U$-test), iPS; induced pluripotent stem, NPAD; Nanog-GFP-positive after differentiation induction, N/C ratio; nucleocytoplasmic ratio. 